Krzysztof Bokwa*

ORCID: 0000-0002-7625-6809

Jagiellonian University in Kraków

Iwo Jarosz ${ }^{* *}$

ORCID: 0000-0003-3671-1982

Jagiellonian University in Kraków

https://doi.org/10.19195/1733-5779.34.12

\title{
The standards of tortious liability in the West Galician Code and its influence on ABGB in light of modern Polish tort law
}

\section{JEL Classification: K36}

Keywords: West Galician Civil Code, Austrian law, obligation law, tort law, legal history

Słowa kluczowe: kodeks cywilny zachodniogalicyjski, prawo austriackie, prawo zobowiązań, odpowiedzialność deliktowa, historia prawa

Abstract: The aim of the article is to describe the general outline of the provisions of the West Galician Code of 1797 regarding standards of tortious liability. To this end, the genesis of this codification and its significance for the development of law in Central Europe is shown. Chosen provisions of Chapter XIII of Part Three of the Code are then discussed and compared, especially those incorporating specific or original regulations, taking into account the relevant provisions in ABGB and the Polish Civil Code. The utilization of comparative, legal-historical and dogmatic methods shall enable showing the evolution and timelessness of certain contract law problems over the last two centuries.

* Scientific Tutor (Opiekun naukowy) - prof. dr hab. Andrzej Dziadzio

** Scientific Tutor (Opiekun naukowy) — prof. dr hab. Fryderyk Zoll 


\title{
Zasady odpowiedzialności deliktowej w zachodniogalicyjskim kodeksie cywilnym i ich wpływ na ABGB w świetle współczesnego polskiego prawa deliktów
}

\begin{abstract}
Abstrakt: Artykuł ma na celu przedstawienie zarysu regulacji zachodniogalicyjskiego kodeksu cywilnego w zakresie odpowiedzialności deliktowej. W tym celu autorzy przedstawiają genezę tej kodyfikacji i jej znaczenie dla rozwoju prawa cywilnego w Europie Środkowej. Stanowi to podstawę szczegółowej analizy wybranych, szczególnie interesujących regulacji rozdziału XIII części trzeciej kodeksu i zestawienia ich z odpowiadającymi im normami zawartymi w austriackim ABGB i aktualnym polskim kodeksie cywilnym. Zastosowanie zróżnicowanej metodologii badawczej (metody komparatystycznej, historycznoprawnej i dogmatycznej) pozwala na ukazanie ewolucji opisywanych aspektów prawa cywilnego w ciągu ubiegłych dwóch stuleci, a zarazem aktualności opisywanych problemów dla współczesnej nauki i praktyki prawa.
\end{abstract}

\section{Introduction}

The West Galician Code ${ }^{1}$ is universally known as the first comprehensive albeit short-lived - codification of civil law in force in the Polish territories. The statute's name is usually briefly mentioned in the much broader context of the General Civil Code of Austria, ${ }^{2}$ for which the WGC served both as a prelude and a kind of "general trial". To research the norms of this exceptional statute, due to its pioneering character, can be both fruitful and instructive for legal historians and practicing civil lawyers alike. The authors aim to compare certain selected, particularly interesting legal institutions to more modern codifications, especially the contemporary Polish Civil Code ${ }^{3}$ as well as its predecessor — the 1933 Polish Code of Obligations. ${ }^{4}$

The WGC is worthy of stricter scrutiny, especially from the perspective of a Polish lawyer. Undoubtedly, many solutions, regulatory questions and approaches to the law developed by the drafters of the WGC have outlived the ephemeral statute. As will be shown, many of the institutions and concepts already present in the WGC have found their way to the subsequently enacted ABGB - itself a monument of civil law that has remained in force since 1811 up to the present. The ABGB had an overwhelming influence over Polish private law as a source of inspiration for the later enacted, chiefly Polish regulations, with the Austrian regulation creating a vast and diverse testing ground for the operation of the law. Moreover, as many Polish lawyers active, during the Second Polish Republic, in the fields of both legal practice and legislation drafting, originated from the Au-

1 Westgalizisches Gesetzbuch, hereinafter referred to as: "WGC".

2 Allgemeines Burgerliches Gesetzbuch, JGS No. 946/1811, hereinafter referred to as: "ABGB".

3 Act of 23 April 1964 - Civil Code (consolidated text: Journal of Laws of the Republic of Poland of 2020, item 1740, hereinafter referred to as: the "Polish Civil Code" or "PCC").

${ }^{4}$ Regulation of the President of the Republic of Poland of 27 October, 1934 - Code of Obligations (Journal of Laws of the Republic of Poland of 1934 no. 82 item 598 as amended, hereinafter referred to as: the "Code of Obligations" or "PCO"). 
strian-ruled Polish lands, they were heavily influenced by the legal culture brought about by the ABGB.

Hence a historical and, simultaneously, legal-comparative perspective on these issues will therefore allow not only for a reflection on European legal heritage, but also to inquire into alternative approaches on issues that are still relevant for contemporary lawyers.

\section{The West Galician Code - a result of codification works in 18th-century Austria}

The Enlightenment period, particularly the 18th century, brought about a plethora of projects aiming at codifying the law across all of Europe. This trend may be said to have stemmed from Austria. The first step toward the unification of Austrian law was taken as early as 1704, during the reign of Leopold I, when the Codex Iuris Austriacus was enacted; it was nothing more than a partial compilation of local laws. The actual beginning of the major codification works occurred when Maria Theresa called, in 1753, the Compilation Committee, whose main objective was to draw up a kind of codicis universalis, bringing together the particular laws of several crown lands. ${ }^{5}$

These codification efforts resulted in the Codex Theresianus of 1766 - an extremely extensive project that, ultimately, never came into force. In 1771, court councilor Johann Bernhard Horten prepared an abridged and revised version of the draft; his bill also remained merely a proposal. ${ }^{6}$ The first comprehensive outcome of several decades' codification efforts in the Habsburg-ruled lands was the Westgalizisches Gesetzbuch, which in 1797 went into force in the parts of Polish lands taken by Austria during the partitions of the Polish-Lithuanian Commonwealth. The WGC was the fruit of several years' work of a brand new commission appointed by Emperor Leopold II, led by Karl Anton von Martini, ${ }^{7}$ who had chosen to model the code on Horten's earlier draft. ${ }^{8}$ It can be regarded as the first of a series of "natural law codifications" in Europe (and thus in the world). ${ }^{9}$ First introduced in "Western Galicia", i.e., the lands occupied during the Third Partition of Poland, ${ }^{10}$ the drafters' intention was that the statute would later rise to be applied in the entire Habsburg monarchy.

5 T. Maciejewski, Historia powszechna ustroju i prawa, Warszawa 2000, p. 734.

${ }^{6}$ K. Sójka-Zielińska, Wielkie kodyfikacje cywilne. Historia i współczesność, Warszawa 2009, pp. 86-87.

7 Karl Anton von Martini, Freiherr zu Wasserburg (1726-1800) — a leading Austrian lawyer of the 18th Century, professor at the University of Vienna, president of the Supreme Chamber of Justice.

${ }^{8}$ K. Sójka-Zielińska, op. cit., pp. 89-91.

9 J. Andrzejewski, Laesio enormis $i$ wyzysk. Tradycja prawna a przeciwdziałanie nieekwiwalentności świadczeń w prawie prywatnym Austrii, Niemiec i Polski, unpublished doctoral thesis, Poznań 2015, p. 46.

${ }^{10}$ By virtue of a patent dated 13.02.1797. 
The code consisted of three parts. The first of these comprised some form of general provisions as well as provisions on personal, family and guardianship law. Chapter I of Part One, entitled "On rights and laws in general", was essential for the purpose of interpreting and understanding the entire Code. It contained explanations of basic notions and provided for certain legal principles that were, at the time, innovative, such as the prohibition of ex postfacto legislation, presumed knowledge of the law (ignorantia iuris nocet), equality before the law ( $\$ 13$ ss. 1) or the primacy of statute over customary law; it also allowed judges to fill in legal lacunae by applying the "natural idea of the statute" and analogy (§ 19 ss. 1). The second part of the WGC concerned property law and inheritance law, therefore it will not be discussed in this paper.

\section{Selected elements of tortious liability in the West Galician Code}

The third part of the WGC, which regulates contract law in its entirety, is the one this paper is concerned with. Tort liability was covered by Chapter XIII of the third part. The first of its provisions $\left(\S 411^{11}\right)$ defined the grounds for liability torts, defined simply as "wrongs" - a "free act or omission contrary to the duties owed to others". ${ }^{12}$ Then, $\S 412$ specified that liability could not stem from events not resulting from "a free act or omission, ones not foreseeable or at least such that cannot be avoided"; this provision was reiterated and clarified in $\S 426$. These issues have been consolidated in the ABGB to comprise its $\S 1306 .{ }^{13}$

This way, the WGC allowed no room for liability imposed with no fault present, such as strict liability ${ }^{14}$ or liability imposed upon actors further to the equity principle, not predicated on wrongdoing, but resulting e.g. from the comparison of parties' standing - both of these being institutions created by civil law scholars at the turn of the 19th and 20th Centuries. ${ }^{15}$ The development of these principles (strict liability, equity principle) stemmed from the inadequacies of fault liability in certain categories of situations, especially where the injured person's vindication would be barred, even though the potential wrongdoer's conduct, otherwise not culpable further to general terms, brought about unusual, grave risk or an imma-

11 In the remaining parts of this paper, provisions of the law quoted without referral to another statue shall be read as referring to Part Three of the WGC, unless otherwise stated.

${ }^{12}$ For the purpose of this paper, the provisions of the WGC quoted herein have been translated by the authors from the German original. Polish-speaking readers cf. the official translation of the WGC into Polish, made and published by Józef Hraszański - Ustawy cywilne dla Galicyi Zachodniey, parts 1-3, Wiedeń 1797.

13 "The damage, which some one has caused without fault or by an involuntary act, he is not bound as a rule to replace" - quoted after: The General Civil Code for All the German Hereditary Provinces of the Austrian Monarchy, trans. by J.M. von Winiwarter, Vienna 1866.

14 Also dubbed "strict liability" by civil lawyers.

15 See A. Dziadzio, Powszechna historia prawa, Warszawa 2009, pp. 354-361. 
nently dangerous situation, even more so where the wrongdoer created the risk in the course of pursuing his own material interests. ${ }^{16}$ Modern Polish law imposes strict liability - i.e., liability independent of wrongdoing on the part of the defendant - in a few categories of situations: (1) linked to occupation of premises or use of buildings, in the following cases: for damages caused by ejection, effusion or falling of any object from the premises (Article 433 PCC), the latter for damages inflicted by a collapse of the construction or by a detachment of its part (Article 434 PCC); (2) stemming from the tortfeasor using the elemental forces of nature (steam, gas, electricity, liquid fuels etc.) in cases related to damages inflicted in the course of operation of an enterprise (Article 435 PCC) or motor vehicles (Article 436 PCC); (3) cases of a principal's vicarious liability for persons entrusted by him with execution of certain tasks (usually employees) (Article 430 PCC; respondeat superior) or liability of persons who raise or employ animals covering the fault of other persons that they entrusted with the animal (Article 431 PCC), (4) with respect to certain types of model contracts described in the $\mathrm{PCC}, \mathrm{e.g}$. the liability of a hotel owner (Article 846 PCC). Article 435 PCC contains what is described as a model catalog of defenses that a defendant can raise in strict liability cases: i) Act of God, ii) exclusive fault of the injured party, iii) exclusive fault of a third party for whom the defendant is not liable. It bears underlining that the current model of liability for incidents related to the use of elemental forces of nature has been regulated similarly almost to the letter in the Polish Code of Obligations of 1934.

In the WGC, the principles of liability were specified in detail in the subsequent sections of the statute $-\S \S 431$ through $433^{17}$ explicitly indicated that damage must not only result from the action of the perpetrator and that action being culpable, but that it must also be unlawful i.e., violate contractual stipulations or a law prescribing that a specific action need be taken or omitted; this was, moreover, a partial repetition of the provision of $\S 411$. In the ABGB the discussed issues have been dealt with in a much more sophisticated manner, by covering in a single clause the conditions of culpability and illegality, constitutive for a claim for compensation for damage ( $§ 1294 \mathrm{cl} .2$ ABGB). That the general standards of liability as to the nature of the damage and the duty to compensate, the principles of fault and illegality were so chaotically dispersed over the WGC, must be considered a major drawback of the statute (and one which was generally dealt with in the course of drafting the ABGB). This may be reflected merely by comparing the volume of Chapter XIII Part 3 of the WGC (consisting of 51 paragraphs)

16 Common lawyers would recognize this reasoning e.g. from the precedential case Rylands v. Fletcher ([1868] UKHL 1, (1868) LR 3 HL 330).

17 In particular, quoting in extenso $\$ 432$ seems noteworthy: "Whoever makes use of his right and, unintentionally, infringes on the rights of another, is not at fault for anything, but merely exercises the right of natural freedom. In such case, ignorance and omission shall not constitute fault". 
and the corresponding Chapter 30 Part 2 of the ABGB (consisting of 49 paragraphs, this given the ABGB's broader scope of regulation).

As for damage compensation, the relevant grounds were to be found in $\S 419$, where an important terminological distinction had been made between "compensation for injury", pertaining to actual loss (damnum emergens), and "full satisfaction", which was to comprise compensation for non-material (moral) damages as well as loss of profit (profit that the injured party could have expected to gain had they not been harmed, lucrum cessans). A similar definition was later found in the ABGB $(\S 1323)$ and remains valid to this day. Here a fundamental difference exists between Austrian and Polish law, the latter underlining the dichotomy of material (monetary) and non-material (moral) damages. ${ }^{18}$ Where, under Polish law, the general principle of tort liability is that material damage must be always compensated (by natural restitution or by pecuniary means, see Article $363 \mathrm{~s} .1$ PCC), the same cannot be said of moral damages: in this case, compensation is due only when the law (statute) provides therefore ${ }^{19}$.

This solution has been taken and arguably made its way to the PCC from Article 157 PCO, whose third section provided that, irrespective of loss of material character, one might claim damages for moral damages - but only where the law so stipulated. It is, however, worth underlining that this dichotomy in Polish law has become blurred by the $1996^{20}$ amendment to Article 448 PCC. Since the enaction of the amendment, Article 448 has provided for actionability of monetary claims and recoverability of moral damages in all cases of personal rights' ${ }^{21}$ infringement. As the catalog of personal rights, which are undefined by statute but construed by scholars and jurisprudence alike as essential values of emotional or psychological significance, commonly accepted in society, ${ }^{22}$ is open and ever-developing, so is the array of grounds for compensation for moral damages. ${ }^{23}$

18 See K. Bokwa, “Odszkodowanie oraz zadośćuczynienie w prawie polskim i austriackim. Rys historyczny i prawnoporównawczy", [in:] Pomniki prawa na przestrzeni wieków, eds. Kacper Górski et al., Kraków 2017, pp. 135-136.

19 See M. Safjan, [in:] Kodeks cywilny, vol. 1. Komentarz. Art. 1-449 10 , ed. K. Pietrzykowski, Warszawa 2020, Legalis/el., commentary to Article 445 PCC, mn. 3.

${ }^{20}$ Act of 23.08.1996 amending the Civil Code (Journal of Laws of the Republic of Poland of 1996 No. 114, item 542).

21 Defined in Article 23 and 24 PCC.

22 Cf. P. Sobolewski, [in:] Kodeks cywilny. Komentarz, ed. K. Osajda, Warszawa 2020, Legalis/el., commentary to Article 23, theses 1-6; J. Regan (Balcarczyk), [in:] Kodeks cywilny. Komentarz, ed. M.Załucki, Warszawa 2019, Legalis/el., commentary to Art. 23, mn. 1-2; S. Dmowski, S. Rudnicki, Komentarz do kodeksu cywilnego. Księga pierwsza. Część ogólna, Warszawa 2009, p. 106; J. Panowicz-Lipska, [in:] Kodeks cywilny, vol. 1. Komentarz do art. 1-352, ed. M. Gutowski, Warszawa 2018, Legalis/el., commentary to Article 23, mn. 1-6.

23 This system is further complicated by the option of the injured party to elect that, in place of compensation being awarded to them, an "appropriate sum" be awarded to a community purpose chosen by that party. 
However, while in such a situation Polish law clearly grants the right to compensation for moral damages by payment of compensation or by recurring payments (Articles 445 of the Civil Code), the Austrian legislator - as was the case with all Germanic legislation at the time - both in the WGC and ABGB, chose not to allow for such a general admissibility. This legislative choice gave rise to numerous scholarly disputes in Austrian academic circles, continuing until now. ${ }^{24}$ An indirect solution was adopted in art. $157 \S 3$ of the Polish Civil Code, stating explicitly that the compensation for non-pecuniary damage is only applicable in cases provided for in the Act.

$\S \S 420-422$ introduced a peculiar distinction between torts grounded in a "fault of reason" and those caused by a "fault of will". The former, resulting from a culpable lack of knowledge or consciousness, were called "oversight", "negligence", while the latter, stemming from deliberate action, were named "malice". A similar dichotomy was also featured in the ABGB, in $\S 1294$ mentioned above. A peculiar set of instructions on how to construe and recognize fault and its degrees, and how these should be reflected in the compensation awarded, was to be found in $\S \S 423-425$. Among them $\S 424$ was particularly important as it provided for a duty of care, albeit in a rather unobvious form, ${ }^{25}$ the failure to observe such duty constituting the main element of fault. Therefore, $\S 425$ equated the degree of fault in cases of "greater oversight" and "wickedness" - this also in terms of the amount of compensation due.

Such a directive as regards the amount of financial compensation, shaped as directly dependent on the type and intensity of fault, was later neither included in the ABGB nor the Polish Civil Code; unquestionably however, the wording of $\S 424$ WGC may be seen to have inspired $\S 1297$ ABGB, though the latter is shaped in a much clearer way. The modern Polish equivalent thereof is Article $355 \S 1$ of the Polish Civil Code - with respect to the duty of care owed in all legal relations. However in the field of tortious liability under the Polish Civil Code, the degree of fault is of secondary importance: liability is imposed upon the tort-feasor even in cases of slight recklessness.

Another essential practical difference between "oversight" and "malice" was established by $\S 428$, which stipulated that in cases of mere "oversight", the perpe-

24 Cf. F. Zoll, "Prawa osobiste w zarysie ze stanowiska prawa prywatnego austriackiego", Czasopismo Prawno-Ekonomiczne 4, 1903, pp. 546 et seq.; concerning Austrian doctrine see R. Strasser, Der immaterielle Schaden im österreichischen Recht, Vienna 1966; F. Bydlinski, "Der immaterielle Schaden in der österreichischen Rechtsentwicklung", [in:] Festschrift für Ernst von Caemmerer zum 70. Geburtstag, Tübingen 1978; E. Karner, H. Koziol, Der Ersatz ideellen Schaden im österreichischen Recht und seine Reform: Gutachten, Wien 2003.

25 "The greatest oversight is made by him who does at all not care about their duties. Whoever, on the contrary, directs all his attention to this, and all his strength to this bearing, shall be deemed free from the smallest degree of oversight. All other countless degrees of oversight are to be found between the above two". 
trator would only be obliged to compensate for the damage; therefore, under the WGC liability for lost profits would not be imposed upon tortfeasors who have caused the loss unintentionally, due to negligence only. This regulation was then taken over to ABGB ( $§ 1324)$ and has been in force to date, finding no equivalent in other modern systems of law, which generally provide for an obligation to make good damage to property regardless of the degree of fault. Exemplary here could be Polish law, where, as stated above, full recoverability of material damages (damage to property) is a principle, without any distinction or prejudice correlated to the degree of fault (intent or lack thereof). Moreover, further to $\S 454 \mathrm{WGC}$, in cases of damage inflicted intentionally, ${ }^{26}$ the injured party could claim not only compensation (redressal of damages), but also "full satisfaction" - i.e., encompassing lost profits and "the value of the peculiar predilection" (also referred to as: pretium affectionis). This provision was then incorporated into ABGB (§ 1331), where it also remained an exception.

In $\S \S 444-446$ WGC the cases of injury to the person have been regulated. $\S 444$ underlined the obligation to cover the costs of treatment, lost earnings and — should such a request be made -"compensation for pain" (Schmerzengeld), which should be understood as a form of rewarding moral damages. $\S 446$ provided for the possibility to demand financial compensation in the event of the death of a father to a family - and if such a death would be brought about by an intentional act, such compensation could also cover the "full satisfaction", which in this case, however, should probably only be understood as compensation for the moral damage, as "further compensation", i.e., loss of means of subsistence, was required in all cases of the aforementioned death of a father. The equivalent of this provision in the ABGB was $\S 1327$, which, however, no longer provided for the possibility to claim compensation for non-material damage.

Another interesting principle could be construed from $\S 445$ WGC, which was, subsequently, repeated in $\S 1326 \mathrm{ABGB}$ almost to the letter. It provided an opportunity to claim compensation "if the person injured has been deformed by the ill-treatment, this circumstance must, especially if the person belongs to the female sex, so far be taken into consideration, as the better success in life may have been prevented by it". ${ }^{27}$ Hence, women could claim pecuniary compensation for any bodily harm which might have affected their success with men — this obviously stemmed from the consideration that such success would also, at least indirectly, affect their financial standing. At the same time, this provision established an unquestionable preference for women, which, as reiterated in the ABGB, remains in force until now. It is worth underlining that contemporary Polish civil law does not directly feature a corresponding regulation, though it would not, arguably, suffer a

26 “....whether it's for profit, hence: robbery, theft, deception, wicked assault, or due to swivel or the joy of harm..."

27 Translation: J.M. von Winiwarter, op. cit. 
person (whatever their gender) wronged in such way as to lead to deformation of the body, especially facial features, to be deserted without remedy. The material damage of such a person would be remedied further to Article $444 \S 1$ PCC ("In the case of bodily harm or a health disorder the redress of the damage shall include all expenditures resulting therefrom"), also to the extent that his prospects for future success have been reduced (whereupon he may demand that the defendant pay recurring payments, see: Article $444 \S 2$ PCC). ${ }^{28}$ Article 445 PCC on the other hand states (and has always stated) that in cases of bodily harm the injured party may claim compensation for non-material damage (harm). It is worth noticing that the Polish Supreme Court has — as early as in 1963 — remarked (albeit — obiter dicta) that the loss of marital prospects may constitute grounds for a compensatory claim for non-material damage. ${ }^{29}$ Nowadays, after the aforementioned 1996 amendment to Article 448 PCC, allowing for compensation for non-material damage for all infringements of personal rights, such an approach to claims resulting from bodily injury and deformation of the body seems even better grounded.

The means of civil law protection awarded to women were further developed in $\S 447$, which provided for tort liability for seducing a woman and conceiving a child with her; the father was obliged not only to fulfill his parental duties but also to cover the costs of childbirth and postpartum. This regulation was supplemented, and in fact repeated in $\S 151 \mathrm{~s}$. $1,{ }^{30}$ which contained a provision of a penal character; this is unquestionably an example of the legislative imperfection of the WGC. These provisions (together with the reference to the corresponding criminal law provisions) were incorporated into the ABGB - as $\S 1328 .{ }^{31}$

Another provision of noteworthy character is $\S 448$, providing for grounds for compensation for unjustified deprivation of liberty through "unlawful arrest, violent imprisonment, private taking into captivity". The injured person had to be freed, and, moreover, the damage suffered and the loss of profit had to be compensated. What is more, $\S 448$ provided for a similar claim on part of "the wife, children and everyone else affected", should the injured person die. A provision with almost identical content was $\S 1329$ ABGB. ${ }^{32}$ Arguably $\S 448$ WGC was a very

28 P. Sobolewski underlines directly that diminished marital prospects fall under the categories of events covered by Article $444 \S 2$ PCC. Cf. P. Sobolewski, [in:] Kodeks cywilny. Komentarz, ed. K. Osajda, commentary to Article 444, item 74.

29 Resolution of the Seven Justices' Panel of the Polish Supreme Court - Civil Chamber legal principle of 17 June, 1963, case no. III CO 38/62.

30 "It for the mother to file action against a deceiver for damages; but if she falsely claims that someone is the father according to the circumstances she is to be punished".

31 "Whoever seduces a woman and begets a child by her, pays the expenses of the confinement and the childbed; and fulfils all the other duties of the father determined in the third chapter of the first part. The criminal code contains in what cases seduction is to be punished at the same time as a crime or as a heavy transgression of the police laws" — translation: J.M. von Winiwarter, op. cit.

32 "Whoever deprives some one of his liberty by forcible abduction, by private imprisonment, or wilfully by an illegal arrest, is bound to procure the person injured his former liberty and to 
innovative piece of legislation, anticipating contemporary regulations, i.e., in the case of Polish law Articles 417 and $446 \S 3$ PCC, and, with respect to compensation and for wrongful conviction, unjustified arrest or detention - the provisions of Chapter 58 of the Polish Criminal Procedure Code.

$\S \S 449-452$ regulated the admissibility of compensation claims for infringement of the "right of good repute", i.e., in cases of slander or defamation. The code imposed liability upon tort-feasors in such cases only covering the extent of actual loss. That aside, civil courts were entitled to impose appropriate penalties under binding criminal laws. In the $\mathrm{ABGB}$, the direct equivalent of the aforementioned WGC provisions with respect to private law was to be found $\S 1330 ;{ }^{33}$ the clause, however, no longer entrusted civil courts with the power to impose criminal sanctions - these were, further to $\S 1339$, referred to the criminal judiciary. This shows the historical process of separating the criminal and civil judiciary, one which had not been yet crystallized while the WGC was being drafted, but had become evident when the ABGB was enacted. What is noteworthy, however, is $\S 452$ WGC, according to which, in the event that a "danger of further injury" existed, it was possible to demand security, either material or through a "warning of a possibility of harsher penalization"; the ABGB contained no such provision, which was, dogmatically speaking, an interesting and original measure, combining the issues of securing future claims with a statutory sanction for repeating civil wrongs - an idea nowadays linked rather to modern criminal legislation, obliging the courts to render stricter judgments for repeated offences (recidivism).

The ultimate provisions of Chapter XIII WGC concerned specific types of liability. $\S 456$ covered damages caused by children and the insane, recognizing that although such damages have an accidental character, there exists nevertheless an obligation to remedy them. ${ }^{34}$ Therefore, $\S 456$ was breakthrough provision as it marked a precedential departure from the principle of fault as the grounds for liability. Simultaneously, the discussed provision is particularly interesting as it regulates the liability for children and the insane differently to the modern principle of fault in supervision (culpa in custodiendo), upon which contemporary Polish law is grounded. Article 427 PCC clearly states that liability is imposed upon persons obliged, by virtue of the law itself or contractually, to supervise persons upon whom fault may not be imputed due to their age or mental or physical capacity (the regulation of the PCC's predecessor, found in Article 142 PCO, was almost identi-

render him full satisfaction. If he cannot procure him his liberty again; he must give his wife and children compensation the same as in the case of killing" - translation: J.M. von Winiwarter, op. cit.

33 "If a real injury or loss of profit has been caused to someone by insults; he is justified in demanding indemnification or full satisfaction" - translation: J.M. von Winiwarter, op. cit.

34 "But, because the reward for the damage is found on the right of defence, which applies also against children as well as the insane, the redressal for such damage, if it is not offered by the party at fault, falls on the injurer". 
cal). This standard of liability set by Article 427 PCC does not, however, amount to strict liability, as the potential defendant is allowed a defense based on him proving that he observed a duty of care in supervision (in other words: the supervisor is not at fault in exercising supervision) or if damage would have also arisen in spite of careful observance of supervision. Hence, the modern Polish model of liability for children or the insane or frail adopts a mixed standard of liability, one that is secondary in that it imposes liability for acts or omission of another person, but not vicarious as it does not constitute strict liability, requiring the superiors fault in infringing acts carried out by another party. Due to this, Polish scholars deem Article 427 PCC not as a departure from fault liability toward strict liability, but merely as a provision tightening the rules of fault-based liability. ${ }^{35}$

Furthermore, $\S \S 457$ and 458 WGC concerned damages inflicted by animals, imposing liability upon those who have driven (led) animals, excited them or neglected to properly guard them. The equivalent of these provisions was in ABGB $\S 1321 .{ }^{36}$ The standard of liability for animals is similar in modern Polish law, as stipulated under Article $431 \mathrm{cl} .1 \mathrm{PCC},{ }^{37}$ requiring fault on part of the defendant (or another person for whom the defendant is liable - hence, with respect to such person's fault, the provision in questions constitutes strict liability, see above). The main difference, as well as a sign of the evolution of the tortious liability regulation, is that the WGC (and ABGB also) stated that in cases where no one is at fault (in driving the animal, exciting it or failure to guard), the injury is to be considered an accident - therefore, one for which no one would be liable. Modern Polish law, however, imposes liability further to the equity principle, stating that even in cases where liability under Article $431 \mathrm{cl}$. 1 PCC is prescribed (i.e., the defendant or a person for whom he is liable are not at fault), the injured party may demand that their damage be redressed in full or in part where it is equitable, namely: if the circumstances, especially the comparison of the parties financial situation (standing) indicate that the principles of community coexistence (equity) require compensation to be awarded.

In cases of damage inflicted in the crops by cattle of another person, the WGC awarded the injured party not only with compensation claims, but also the right to distrain as "many a head of cattle as are sufficient to compensate him"; the rights of the injured party, therefore, were much vaster than in the case of the statutory pledge known in the modern Polish Civil Code (Article 432 PCC), where under

35 See M. Safjan, [in:] Kodeks cywilny, vol. 1. Komentarz. Art. 1-449 $9^{10}$, commentary to Article 427 PCC, mn. 1.

36 "If someone is injured by an animal, he who has driven it, who has excited it or has neglected to guard it, is answerable for it. If no one can be convicted of a fault of this sort, the injury is to be considered as an accident" — translation: J.M. von Winiwarter, op. cit.

37 Stating: "Who raises an animal or uses it shall be obliged to redress the damage inflicted by it, regardless whether the animal has been under his supervision or if it has strayed or escaped, unless neither himself nor the person who he is liable for are at fault". 
a possessor of land may seize somebody else's animal which inflicts damage on the land, obtaining thus a statutory pledge securing he redress of the damage as well as the costs of the animal's feeding and maintenance - provided that securing the compensatory claim is necessary; hence, in cases where satisfaction of claims from the tort-feasors property is not in doubt, no right to seize the animal would arise. ${ }^{38}$

\section{Final remarks}

Evaluating the WGC from the viewpoint of contemporary Polish tort law jurisprudence and scholarship, one notices immediately that the WGC and modern Polish tort law differ in the dogmatic-philosophical approach toward intent and fault (errors of will or errors of reason) and that the dichotomy between material and non-material damages is defined in a different way. This cannot be surprising, given the distance of two centuries, dividing the two codifications. Attention should be drawn to how narrowly non-material damage (harm) was defined, a development typical for the Austrian and German legal landscape (differing substantially from the Polish approach), which has resulted in numerous controversies in these legal systems arising up to date.

On the other hand, the comparison of the WGC and ABGB shows that significant similarities exist between them, justifying the latter being perceived as a direct continuation of the experimental West Galician Code. As in the several years that had passed between the enactment of either of the statutes, the quality of the regulation and the systematics thereof improved significantly - the ABGB may be, therefore, seen as a creative development upon the WGC as well as a refinement of the previous statute. Given that many of the WGC provisions, incorporated subsequently into the $\mathrm{ABGB}$, remain binding till today, one may not only see their long continuity, but also appreciate the craft of the Austrian legislators from the 18th-19th centuries and how they successfully disposed of numerous social problems requiring regulation - issues related to cooperation and conflicts alike - that they faced in the course of drafting both codes.

It may, therefore, be said that the inquiry into the legislative achievements of drafters active in the time of enlightened absolutism, proves that the issues that were problematic and controversial then still remain so. A careful analysis of the provisions of the WGC - the first modern codification of civil law in Central Europe - may prove fruitful not only from the legal-historical perspective, but also for contemporary dogmatic legal studies.

38 J.M. Kondek, [in:] Kodeks cywilny. Komentarz, ed. K. Osajda, commentary to Article 432, item 3 . 


\section{References}

Andrzejewski J., Laesio enormis $i$ wyzysk. Tradycja prawna a przeciwdziałanie nieekwiwalentności świadczeń w prawie prywatnym Austrii, Niemiec i Polski, unpublished doctoral thesis, Poznań 2015.

Bokwa K., "Odszkodowanie orazzadośćuczynienie w prawie polskimi austriackim. Rys historyczny i prawnoporównawczy", [in:] Pomniki prawa na przestrzeni wieków, eds. Kacper Górski et al., Kraków 2017.

Bydlinski F., "Der immaterielle Schaden in der österreichischen Rechtsentwicklung", [in:] Festschrift für Ernst von Caemmerer zum 70. Geburtstag, Tübingen 1978.

Dmowski S., Rudnicki S., Komentarz do kodeksu cywilnego. Księga pierwsza. Część ogólna, Warszawa 2009.

Dziadzio A., Powszechna historia prawa, Warszawa 2009.

General Civil Code for All the German Hereditary Provinces of the Austrian Monarchy, trans. J.M. von Winiwarter, Vienna 1866.

Grodziski S., "Uwagi z okazji jubileuszu austriackiego kodeksu cywilnego z 1811 roku”, Czasopismo Prawno-Historyczne 63, 2011, issue 2.

Hraszański J., Ustawy cywilne dla Galicyi Zachodniey, parts 1-3, Wiedeń 1797.

Karner E., Koziol H., Der Ersatz ideellen Schadens im österreichischen Recht und seine Reform: Gutachten, Wien 2003.

Kodeks cywilny, vol. 1. Komentarz do art. 1-352, ed. M. Gutowski, Warszawa 2018, Legalis/el.

Kodeks cywilny, vol. 1. Komentarz. Art. 1-44910, ed. K. Pietrzykowski, Warszawa 2020, Legalis/el. Kodeks cywilny. Komentarz, ed. K. Osajda, Warszawa 2020, Legalis/el.

Kodeks cywilny. Komentarz, ed. M. Załucki, Warszawa 2019, Legalis/el.

Maciejewski T., Historia powszechna ustroju i prawa, Warszawa 2000.

Strasser R., Der immaterielle Schaden im österreichischen Recht, Wien 1966.

The General Civil Code for All the German Hereditary Provinces of the Austrian Monarchy, Vienna 1866, translated by J.M. von Winiwarter.

Sójka-Zielińska K., Wielkie kodyfikacje cywilne. Historia i współczesność, Warszawa 2009.

Zoll F., "Prawa osobiste w zarysie ze stanowiska prawa prywatnego austriackiego", Czasopismo Prawno-Ekonomiczne 4, 1903. 